Document downloaded from:

http://hdl.handle.net/10251/57453

This paper must be cited as:

Marín García, JA.; Bonavía Martín, T.; Maria Losilla, J. (2011). Exploring working conditions as determinants of job satisfaction: an empirical test among Catalonia service workers. Service Industries Journal. 31(12):2051-2066. doi:10.1080/02642069.2011.559226

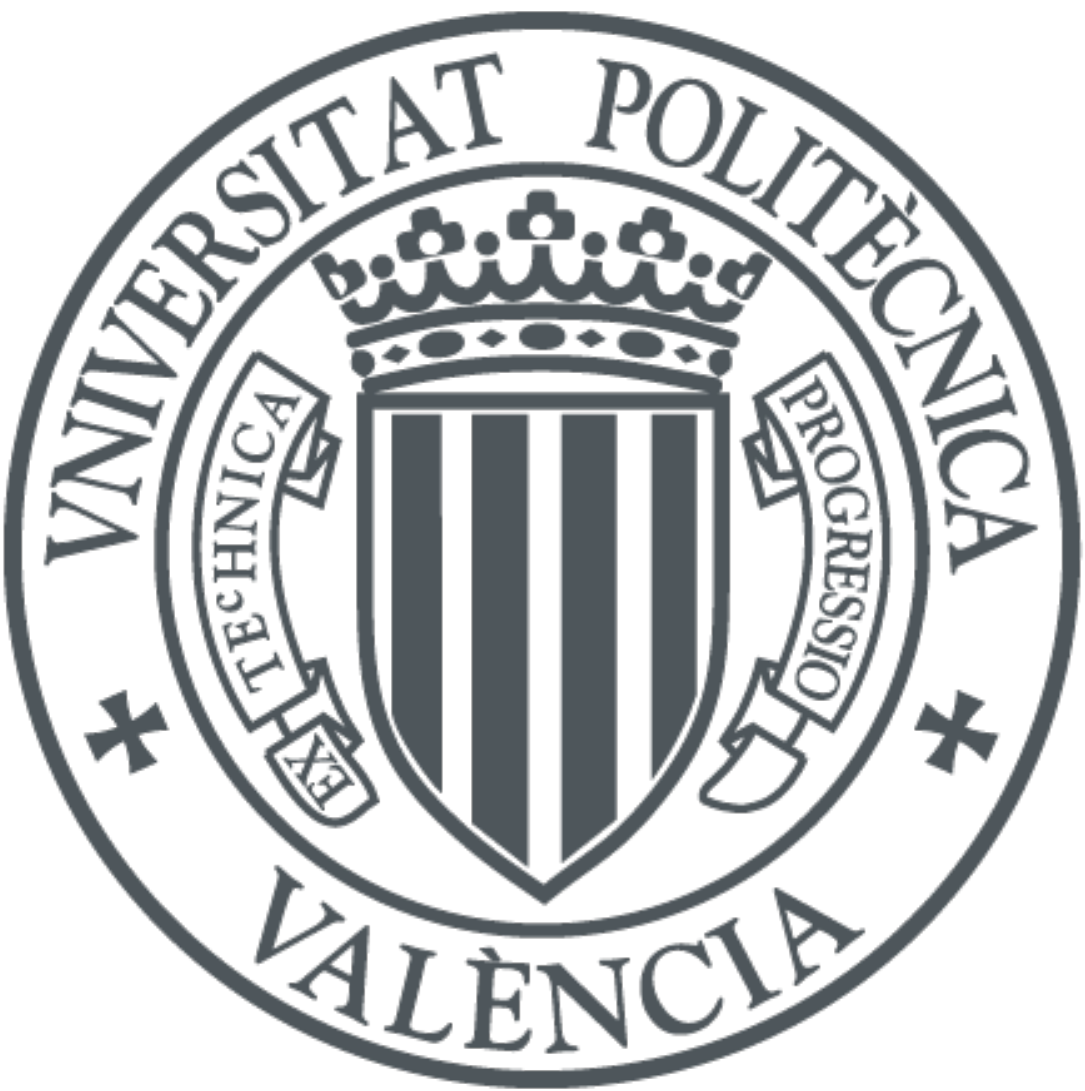

The final publication is available at

http://dx.doi.org/10.1080/02642069.2011.559226

Copyright Taylor \& Francis (Routledge): SSH Titles

Additional Information 
The final version of this paper was published in:

Marin-García, J. A.; Bonavia, T. y Losilla, J. M. (2011). Exploring working conditions as determinants of job satisfaction: an empirical test among Catalonia service workers. The Service Industries Journal, 31 (12), 2051-2066.

\title{
Exploring working conditions as determinants of job satisfaction: an empirical test among Catalonia service workers
}

\author{
Juan A. Marin-Garcia \\ ROGLE- Dept. Organización de Empresas \\ Universidad Politécnica de Valencia \\ ETSII-Edificio 7D \\ Camino de Vera s/n 46022 Valencia-SPAIN \\ jamarin@omp.upv.es
}

\section{Tomas Bonavia}

Universitat de Valencia.

Facultad de Psicología

Dept. de Psicología Social

Av. Blasco Ibáñez, 21

46010 VALENCIA

Tomas.Bonavia@uv.es

\section{Josep-Maria Losilla}

Dept. de Psicobiologia i de Metodologia de les CC. de la Salut

Edificio - Campus de la Universitat Autònoma de Barcelona

08193 - Bellaterra (Cerdanyola del Vallés) - Barcelona - Spain

JosepMaria.Losilla@UAB.cat

Department, University, City, Country

(Received XX Month Year; final version received XX Month Year)

\footnotetext{
Job satisfaction is particularly important in the service industry since it involves direct contact with customers and thus has a direct influence on company performance. We analyzed the impact of ten working conditions on job satisfaction by means of structural equation modelling in a representative stratified random sample of 1553 service sector employees in Catalonia (Spain). We found significant effects in social aspects (recognition of a job well done and social support), followed by psychological loads (emotional demands and job insecurity) and by task contents (development \& meaning and predictability). These variables explained $50 \%$ of the variance in job satisfaction.
}

Keywords: Working conditions; job satisfaction; service sector; structural equation modelling; job characteristics; service workers 


\section{Introduction}

The work environment of the majority of current occupations in developed countries is characterized by an increase in complexity, more team work, polyvalence, decentralized decision making, the use of sophisticated technology, growth in competition and the necessity to reduce costs (Tummers, Landeweerd, \& Van Merode, 2002; Noblet, Teo, McWilliams, \& Rodwell, 2005; Tortosa-Edo, Sanchez-Garcia, \& Moliner-Tena, 2010). These factors generate an increase in the psychological pressure created in the workplace (Tummers et al., 2002; de Jonge et al., 2001). The psychosocial factors are determined by the specific characteristics of the job (work organization, demands, task content and social aspects) that determine the conditions of the working environment, and have the ability to affect the wellbeing of the worker as much as the progress of the work in hand (Martín García, Luceño Moreno, Jaén Díaz, \& Rubio Valdehita, 2007; Tummers et al., 2002). In fact, psychosocial factors are becoming more important as an explanatory variable of worker wellbeing than physical work requirements (Morrison, Cordery, Girardi, \& Payne, 2005; Noblet et al., 2005; Shiu \& Yu, 2010).

The service sector is now an important part of the economy, both in terms of turnover as well as in the number of people it employs (Li, Yang, \& Wu, 2008; Lee, Olson, Lee, Hwang, \& Shin, 2008). In this type of company, in which the employee/customer relationship (either face-to-face or via technology) is increasingly important, the relation between working conditions and job satisfaction is more marked than in other sectors (Tummers et al., 2002; Paulin, Ferguson, \& Bergeron, 2006; Al Juhani \& Kishk, 2006). Within the service sector a positive association has been found between job satisfaction and company efficiency (Noblet et al., 2005; Chen \& Chen, 
2008; Brown \& Lam, 2008; Li et al., 2008; Coelho, Augusto, Coelho, \& Sa, 2010; Ekinci \& Dawes, 2009; Iglesias, 2009).

The objective of this paper is therefore to study working conditions in the service sector (demands, job insecurity, influence, development and meaning, social support, role clarity, quality of leadership, predictability and esteem) and to examine their relative and joint effect on job satisfaction.

For the study we used quite a large representative stratified random sample $(\mathrm{N}=$ 1553) consisting of service workers from Catalonia (Spain). An additional motive was to adapt for the service sector previously used broad models that had combined data from construction, service and industry (Kil, Leffelsend, \& Metz-Gockel, 2000; Pires, Sarkar, \& Carvalho, 2008).

This study extends previous lines of investigation published in the literature in a relatively under-investigated field (Tummers et al., 2002). The relationship between working conditions and job satisfaction is now thought to be more complicated than has been indicated in the literature (Morrison et al., 2005). Also, further studies with sizeable heterogeneous sample groups (multiple companies with different activities) are necessary to simultaneously incorporate differing independent variables (Schyns \& Croon, 2006). In our study, we used a heterogeneous representative transversal sample of a population that had not been previously analyzed in this way, which gives strength to the replication and assessment of models (Schyns \& Croon, 2006; Brown \& Lam, 2008; de Jonge et al., 2001; Roelen, Koopmans, \& Groothoff, 2008). Our sample size also allowed us to increase the number of explanatory variables and to apply a rigorous methodology (Structural Equation Modelling) (ter Doest \& de Jonge, 2006; Tummers, Van Merode, \& Landeweerd, 2006; Roelen et al., 2008; Karsh, Booske, \& Sainfort, 2005). 
We believe our project also has a practical interest, in that it can be used by companies to design and adapt jobs (Brown \& Lam, 2008; Chen \& Chen, 2008) and thus provides service sector managers with information that could help them to prioritize those changes with the most positive impact on improving job satisfaction.

\section{Satisfaction at work}

Satisfaction in the workplace can be defined as a positive emotional orientation towards work. It is the result of the perception that the task undertaken is consistent with the values of the worker and contributes to the satisfaction of his personal needs (Al Juhani \& Kishk, 2006; Hackman \& Oldham, 1980; Brown \& Lam, 2008; Noblet et al., 2005). When it comes to establishing an operative definition for this concept, various strategies have been used. Some authors have considered it in terms of a global factor, while others have separated it into different job facets, such as intrinsic, extrinsic, salary, interpersonal relationships, development, etc. (Al Juhani \& Kishk, 2006; Brough, 2005; Brown \& Lam, 2008).

In the recent literature on job satisfaction, there is abundant evidence that this variable contributes to improving both worker performance and company results (Snipes, Oswald, LaTour, \& Armenakis, 2005; Hsu \& Wang, 2008; Taris, Schreurs, Eikmans, \& van Riet, 2008; Ritter \& Anker, 2002; Hung \& Wong, 2007; Tian \& Pu, 2008), especially in the service sector (Lim, Ribeiro, \& Lee, 2008; Brown \& Lam, 2008; Noblet et al., 2005; Linz, 2003; Scott, Gravelle, Simoens, Bojke, \& Sibbald, 2006; Kuo, 2007; Li et al., 2008; Love, Irani, Standing, \& Themistocleous, 2007; Shiu \& Yu, 2010). Other studies consider satisfaction as a dependent variable which is expressed in terms of specific conditions in the organizational context. However, a considerable amount of work remains to be done before researchers can propose, or validate, realistic and complete models of the way that workers experience work 
conditions and how this affects their level of satisfaction (Hsu \& Wang, 2008; Petrescu \& Simmons, 2008).

\section{Working conditions}

A job consists of one or more functions (each function composed of a group of tasks or activities) undertaken by a person in a company at a given time (Cascio, 1989), with certain characteristics and influenced by a number of psychosocial factors (Hackman \& Oldham, 1980; Tummers et al., 2002; Thompson \& Prottas, 2006; ter Doest \& de Jonge, 2006; Noblet, Graffam, \& McWilliams, 2008; De Rijk, Nijhuis, \& Alexanderson, 2009; Van den Broeck, Vansteenkiste, De Witte, \& Lens, 2008; Sparr \& Sonnentag, 2008; Schyns \& Croon, 2006; Love et al., 2007; de Jonge et al., 2001; Houkes, Janssen, de Jonge, \& Bakker, 2003; Yang, 2009; Karatepe \& Kilic, 2009). For a worker to perform at his maximum level, it is necessary that he should have or acquire the knowledge, abilities and aptitudes necessary for the completion of the tasks in hand. However, it is also necessary that his personality, interests and desires fit in with the characteristics of the work in such a way that he experience meaning and he gets satisfaction from the job he is doing (de Jong, van der Velde, \& Jansen, 2001).

The most frequently studied variables in the literature are psychological demands, influence, and social support (Karasek et al., 1998; Love et al., 2007; Tummers et al., 2002; Schyns \& Croon, 2006; Morrison et al., 2005; Hackman \& Oldham, 1980). Psychological demands (certain authors have named this "workload") are an indicator of the difficulty of the task in relation to the mental or emotional load, work speed or overload, but does not take into account physical loads, risks or ergonomics. Influence (certain authors refer to it as "control", autonomy or active work) refers to the fact that workers are able to decide certain questions on their own. Social support refers to all possible levels of social relations at work, with both colleagues and 
superiors. In general, it is considered that psychological demands are negatively associated with job satisfaction; while the ability to influence one's job and social relationships are aspects that contribute to job satisfaction (Noblet et al., 2005; Karsh et al., 2005; Tummers et al., 2002).

However it is still necessary to widen this research, increasing the number of explanatory variables to consider the realities of the modern workplace and roles (Morrison et al., 2005) and to clarify the degree to which each job characteristic relates to satisfaction levels (de Jonge et al., 2001). In relation to this, other working conditions used in previous research, albeit with lower frequency, are: job insecurity, the meaning of the tasks undertaken, role clarity, quality of leadership, predictability and recognition of a job well done (Hsu \& Wang, 2008; Moncada Lluis, Llorens Serrano, Font Corominas, Galtes Camps, \& Navarro Gine, 2008; Karasek et al., 1998; Tummers et al., 2002; Uppal, 2005; Wakkee, Elfing, \& Monaghan, 2010).

\section{Objectives and hypothesis}

The purpose of this paper is to establish a framework that allows us to understand how service sector working conditions can be used to reinforce job satisfaction.

To this end we have set out the model we intend to test in Figure 1. This model integrates the contributions of various studies commented in the theoretical framework (Karsh et al., 2005; Tummers et al., 2002; Hsu \& Wang, 2008; Moncada Lluis et al., 2008; Kristensen, Hannerz, Hogh, \& Borg, 2005; Moncada, Llorens, Navarro, \& Kristensen, 2005).

Please insert Figure 1 here

We can summarize this model with the following hypothesis: 
H.1- Quantitative demands have a negative effect on job satisfaction.

This factor is defined as the relationship between work demands and the availability of time to cope with the work to be done. If there is not enough time, the demands present themselves as a fast work pace, the impossibility of completing the task in hand, or the accumulation of work, and can also be related to the irregular time distribution of tasks. As previous research has shown (de Jonge et al., 2001; Yu, Gu, Zhou, \& Wang, 2008; Van den Broeck et al., 2008; Sanchis-Palacios \& Ribeiro, 2010), quantitative demands have a significantly negative impact on job satisfaction.

H.2- Emotional demands have a negative effect on job satisfaction.

This type of demand affects our feelings and the need to keep them hidden in the workplace. This situation frequently occurs when services are offered to the public in which only professional abilities are exercised and personal feelings are left to one side. Previous research shows that emotional demands have a significantly negative impact on job satisfaction (de Jonge et al., 2001; Yu et al., 2008; Van den Broeck et al., 2008; Sanchis-Palacios \& Ribeiro, 2010).

H.3- Job insecurity has a negative effect on job satisfaction.

It refers to contractual insecurity (the fear of losing one's job) and insecurity surrounding other conditions at work. There is evidence that working under contract for a limited time rather than in a permanent position has a strong impact on job satisfaction. Likewise, the insecurity surrounding other conditions at work (changes in shift patterns, salary or career path) are negatively correlated with job satisfaction (Martínez Navarro, 2008; Moncada Lluis et al., 2008; Janus, Amelung, Gaitanides, \& Schwartz, 2007; Zarafshani \& Alibaygi, 2009).

H.4- Influence has a positive effect on job satisfaction. 
This factor is defined as the extent of the control that workers have over their jobs: sequence, amount of work, methods to be used and tasks to be undertaken. A positive relationship appears in the research between job satisfaction and influence (ter Doest \& de Jonge, 2006; de Jong et al., 2001; Tummers et al., 2002; Petrescu \& Simmons, 2008; Thompson \& Prottas, 2006; Roelen et al., 2008; Chen \& Chen, 2008).

H.5- Development and meaning has a positive effect on job satisfaction.

This refers to the evaluation of whether a job provides opportunities for the development of personal abilities and knowledge and if workers can relate their work role to their values or end results other than simply utilitarian ones (to have one's time occupied and to obtain a reward for work completed). Between these two variables (which we deal with as if they were only one), the ability for personal development probably has the most weight (Kuokkanen, Suominen, Harkonen, Kukkurainen, \& Doran, 2009; de Jong et al., 2001; Chen \& Chen, 2008), but the meaning of work has also found support in the literature (Ritter \& Anker, 2002).

H.6- Social support has a positive effect on job satisfaction.

This variable is defined as the possibility of being able to have social relationships in the workplace and to receive whatever help is necessary at any given moment from either colleagues or superiors. Significant relationships have been found in this area between managers and staff support and job satisfaction (Schyns \& Croon, 2006; Noblet et al., 2005; de Jonge et al., 2001; Van den Broeck et al., 2008; Wakkee et al., 2010).

H.7- Role clarity has a positive effect on job satisfaction.

This factor has to do with clearly defined job descriptions: limits, objectives, tasks to be undertaken and expectations. Tummers et al. (2002), Karsh et al. (2005), Sakires (2009) and Albion (2008) found this effect in their studies. 
H.8- Quality of leadership has a positive effect on job satisfaction.

This variable refers to the extent that managers plan work well in advance and maintain good communications with employees. Several authors have found the effect of this variable on job satisfaction (Moncada, Llorens, \& Kristensen, 2004; Shiu \& Yu, 2010; Moncada et al., 2010; Choi, Seo, Scott, \& Martin, 2010; Gonzalez \& Garazo, 2006; Lopez-Cabarcos, Vazquez-Rodriguez, \& Montes-Pineiro, 2010; Rooney, Gottlieb, \& Newby-Clark, 2009; Sellgren, Ekvall, \& Tomson, 2008; Skakon, Nielsen, Borg, \& Guzman, 2010).

H.9- Predictability has a positive effect on job satisfaction.

This refers to the availability of appropriate, sufficient and timely information to adapt to any changes that may affect work. Moncada et al. (2004); Mohr and Wolfram (2010) and Stetz et al. (2007) found evidence for this effect.

H.10- Esteem has a positive effect on job satisfaction.

This factor is defined as the recognition of a job well done. Van den Broeck et al. (2008), Linz (2003), Stocker et al. (2010) and Srivastava and Rangarajan (2008) obtained significant effects for this variable on job satisfaction.

\section{Methods}

\section{Study sample}

The data analyzed comes from "The First Survey of Working Conditions in Catalonia" (Martínez Navarro, 2008). The target population consisted of all service sector employees in Catalonia affiliated to groups of more than one person in the National Insurance System (1,370,369 people).

A stratified random sampling by company size (4 levels), gender (2 strata), and activity sector (4 strata) was applied. The sample size was fixed at 1553 persons. The 
questionnaire was answered by workers via an interview at their home, with reference to the job they were doing at the time of the interview. In those cases where the employee was not at home, or refused to participate, he/she was substituted by another person from the same sector, similar company size and gender. The global sample error was $1.8 \%$, with values between $4.7 \%$ and $5.4 \%$ for the activity subsector, between $2.8 \%$ and $5.6 \%$ for company size, and between $2.4 \%$ and $2.7 \%$ for gender (Martínez Navarro, 2008). The study sample can therefore be considered as high quality and representative of the entire population of service workers. The demographic characteristics of the study sample are given in Table 1.

\section{Please insert Table 1 here}

\section{Measurements}

The questionnaire contains 64 questions and can be answered fully in approximately 30 minutes. For the purposes of this paper we will use only the 34 variables relating to working conditions and job satisfaction. The complete questionnaire can be consulted in Martínez Navarro (2008).

Job satisfaction was measured by only one item ("In general, to what degree do you feel satisfied by your working conditions?"), with four response levels (1.-very satisfied, satisfied, dissatisfied, 4.-very dissatisfied). The strategy of measuring the global satisfaction level by only one item has previously been used in different studies (Roelen et al., 2008; Petrescu \& Simmons, 2008; Hsu \& Wang, 2008; de Jonge et al., 2001) and is considered to be equally valid and reliable as the measurement of job satisfaction by scales (Brown \& Lam, 2008).

Working conditions were measured in the Catalonian survey by the questionnaire PSQ CAT21-COPSOQ, the short format version in Catalan language of CoPsoQ (“Copenhagen Psychosocial Questionarie”) (Kristensen et al., 2005; Moncada 
et al., 2005). All the items of the working conditions constructs had five response categories: "5.-Always / Often / Sometimes / Rarely / 1.-Never". The items were grouped into 10 factors representative of the dimensions of the working conditions (see Table 2).

Please insert Table 2 here

\section{Analysis}

A full latent structural model (Byrne, 2006) with maximum likelihood method was used for parameter estimation with Structural Equations Programme, EQS (Ullman \& Bentler, 2004; Bentler, 2002). Job satisfaction was introduced as a latent variable with a single item indicator setting unstandardized variance error to non-zero value (Standard Deviation $^{2} \mathrm{x}$ (1-worst $\alpha$ Cronbach of other constructs)), considering that this indicator seems unlikely to perfectly estimate the construct (Anderson \& Gerbing, 1988; Brown, 2006).

Furthermore, the analyses were adjusted for gender, age and company size (Van den Broeck et al., 2008; ter Doest \& de Jonge, 2006). Since these adjustments did not improve the accuracy of the results, we only report results from the final model without these variables.

We used several parameters to assess the goodness of fit of the model: Normed Chi $2<5$; CFI (Comparative fit index) >0.90; GFI (Lisrel Fit Indice) >0.85 and RMSEA (Root mean square error of approximation) <0.08 (Tari, Molina, \& Castejón, 2007; Hair, Anderson, Tatham, \& Black, 1999; Ullman \& Bentler, 2004; Spreitzer, 1995). We will also check that the values of Cronbach $\alpha$ of each construct are greater than 0.6 (Lin, 2006; Hair et al., 1999). 


\section{Results}

A preliminary step in the analysis of the full latent structural model is to first test for the validity of the measurement model (Byrne, 2006; Hair et al., 1999; Bagozzi, 1994; Hogan \& Martell, 1987). The values for goodness of fit of each of the constructs are adequate. The Cronbach $\alpha$ of all factors but role clarity and quantitative demands are greater than the recommended cut-off value (see Table 2). Most of the correlations between working conditions were low or moderate but significant (see Table 3).

Please insert Table 3 here

After checking the validity of the measurement model, the relationship between working conditions and job satisfaction was evaluated using the full latent structural model (Figure 1). The correlations between the explanatory variables were included in the full latent structural model but are not showed in Figure 2 for clarity (see Table 3). We can globally consider it as a good fit (Normed Chi2 $=3.62 ; \mathrm{CFI}=0.88 ; \mathrm{GFI}=0.89$ and RMSEA <0.042). All observed variables had significant loadings ranging from 0.31 to $0.88(\mathrm{p}<0.001)$ on their latent factor. A reliable measurement model was thus obtained. Working conditions together explain nearly $50 \%$ of the variance in job satisfaction. The positive and significant effects on job satisfaction are esteem (0.40), predictability (0.17), development \& meaning (0.15) and social support (0.13). Emotional demands (-0.13) and job insecurity (-0.06) have a negative significant effect. In our global service sample, quantitative demands, role clarity, influence and quality of leadership have no significant effects (see Figure 2).

Please insert Figure 2 here 


\section{Discussion}

Regarding our first three hypothesis, the previously published investigation had identified the negative impact of psychological loads (emotional demands, job insecurity and quantitative demands) on job satisfaction. The correlation values showed in previous literature are between -0.13 and -0.30 (Van den Broeck et al., 2008; Thompson \& Prottas, 2006; Tummers et al., 2002; Brough, 2005; ter Doest \& de Jonge, 2006; Moncada Lluis et al., 2008). Our correlation data are in line with previous research. The structural model reinforces these results and identifies negative and significant effects from emotional demands and job insecurity on job satisfaction. However, it fails to find effects from quantitative demands. This may be due to the lack of internal consistency of the scale used, and it is suggested to analyse in detail this scale in future research, for example, by reformulating the item V34.cInv or by adding new items.

On the other hand, influence on decisions has been positively correlated with job satisfaction in various papers, with significant values between 0.18 y 0.34 (ter Doest $\&$ de Jonge, 2006; de Jong et al., 2001; Tummers et al., 2002; Van den Broeck et al., 2008; Thompson \& Prottas, 2006). The correlation obtained by our sample $(0.33)$ is more or less in line with these results. However, in the structure model the effect did not appear to be significant, coinciding with Linz (2003), but disagreeing with the results of other studies, in which it was found to be significant (Petrescu \& Simmons, 2008; Thompson \& Prottas, 2006). This result rejects our hypothesis 4 . It is possible that, as indicated by Schyns and Croon (2006), the tasks in end-workers of some services are not especially motivating or attractive, nor can they be easily enriched by adding influence.

Social support is another factor that is well referenced in the literature. Its correlation with job satisfaction appears to be clear, with values between 0.31 and 0.53 
(Schyns \& Croon, 2006; Tummers et al., 2002; Thompson \& Prottas, 2006; ter Doest \& de Jonge, 2006; de Jong et al., 2001). Our work supports the findings of previous papers, confirming the positive, significant correlation (0.46), as well as the significant effect in the structure model.

H.7 is another rejected hypothesis which appears to be significant in other papers (Tummers et al., 2002; Karsh et al., 2005), but is not seen to be significant in ours. One of the reasons would be the low reliability of the scale, like in H.1 rejection. But also, Nielsen and Cleal (2010) have been found that role clarity not to predict satisfaction at work.

It could be thought surprising that quality of leadership was not seen to be significant in the structure model (rejecting our hypothesis 8), despite its having a moderate correlation with job satisfaction (0.57). Boshoff and Mels (1995) found that the main aspects of quality of leadership (initiating structure or consideration) does not directly influence satisfaction, but does so indirectly by reducing role conflict. Therefore it is recommended for future research to analyze models including some of our variables as mediating variables (Cicero, Pierro, \& van Knippenberg, 2010; LopezCabarcos et al., 2010).

The correlations we obtained between job satisfaction and development \& meaning (0.39), or esteem (0.65) are in line with those obtained by Van den Broeck et al. (2008). We also found high correlations of predictability (0.53) (Zacharatos, Hershcovis, Turner, \& Barling, 2007). Their effects on job satisfaction have also been seen to be significant in the structure model (Linz, 2003). Our findings support previous research regarding the relationship between esteem and satisfaction generalizing the results obtained in armed forces (Stocker, Jacobshagen, Semmer, \& Annen, 2010) or sales forces (Srivastava \& Rangarajan, 2008) in other industries. 
To sum up, hypothesis H.2, H.3, H.5, H.6, H.9, and H.10 were confirmed with our data. In our study, the working conditions that most affect job satisfaction appear to be concentrated in social aspects (esteem and social support), followed by psychological loads (emotional demands and job insecurity) and, to a lesser extent but still with significant effects, by task contents (development \& meaning and predictability). Our results thus appear to be in line with those of various other authors (Tummers et al., 2002; Schyns \& Croon, 2006; Uppal, 2005; Noblet et al., 2005).

Lastly, the explained variance of our model $(50 \%)$, is in line with previous published research, such as 54\% in Roelen et al. (2008) or the 53\% of Karsh et al. (2005), both of which used samples of only one occupational subsector, and goes beyond Thompson and Prottas (2006), where the job characteristics explain the $33 \%$ variance in satisfaction. On the other hand, in those papers where the relationships between working conditions and employees' psychological reactions (such as job satisfaction, for example) are analyzed, the variance explained by the models tends to be low. This is due to the fact that the variance of the dependent variable is not excessive, meaning we are therefore dealing with a sample with a high level of job satisfaction (Tummers et al., 2006).

Other lines of research suggested by our findings would be: (1) to check if the effect of working conditions on job satisfaction, as shown by workers in the service sector, is replicated in other representative samples of employees in industrial or construction settings; (2) to analyze the effect of organizational characteristics as a mediator or moderator in the relationships between working conditions and satisfaction, and to analyze models of mediation between working conditions to detect direct and indirect effects (Morrison et al., 2005; Tummers et al., 2006); and (3), a more detailed 
investigation of the questionnaire measurement model (COPSOQ short form) would be needed to eliminate the limitations of some of the subscales (Roelen et al., 2008), especially role clarity and quantitative demands.

One of the limitations of our research is that the sample was taken from only one Spanish region (Catalonia), so that the results cannot be extended to the whole of Spain or other countries. Another limitation is that all data were based on self-reporting; moreover, the data are cross-sectional and the temporal sequence of the relationships between the variables cannot be clearly evaluated. With this in mind, we should be cautious when interpreting the relationships as causal. It should also be said that most of these limitations are common to other papers published in this field (Tummers et al., 2006; ter Doest \& de Jonge, 2006; Noblet et al., 2005; Schyns \& Croon, 2006).

\section{Conclusions}

Job satisfaction is an important variable in all types of companies, but even more so in the service sector. Our research makes diverse contributions to the literature on the subject, amongst others: it expands upon recent research by other authors (Brown \& Lam, 2008; Tummers et al., 2006; Noblet et al., 2005); it uses a sample size big enough to simultaneously include a wide number of explicative factors (10 working conditions) (Karsh et al., 2005); and it analyzes them using rigorous methodology in the form of Structural Equation Modelling (ter Doest \& de Jonge, 2006; Alves \& Raposo, 2009).

This provides both academics and service sector companies with a greater understanding and calibration of the effect of working conditions on job satisfaction. In this way, service companies can make better decisions when modifying the characteristics that have the greatest impact on job satisfaction. The greatest effect would be obtained by providing social support in hard times and by superiors giving recognition for work well done. Similar effects would be obtained from the general 
support provided by work colleagues and bosses, possibly facilitating group work. Job satisfaction could also be improved through better work organization and allowing employees ways to express their emotions. Finally, providing information to employees on any changes that may affect their work and their future is another important element in achieving satisfaction at work.

\section{Acknowledgements}

This research was supported by Grant PSI2010-16270 from the Spanish

Ministry of Science and Innovation. We also thank the Department of Labor of the Government of Catalonia for their permission to use the data of I-ECTC. The translation of this paper was funded by the Universidad Politécnica de Valencia, Spain.

\section{REFERENCES}

Al Juhani, A. M. \& Kishk, N. A. (2006). Job satisfaction among primary health care physicians and nurses in Al-madinah Al-munawwara. Journal of the Egyptian Public Health Association, 81, 165-180.

Albion, M. J., Fogarty, G. J., Machin, M. A., \& Patrick, J. (2008). Predicting absenteeism and turnover intentions in the health professions. Australian Health Review, 32, 271-281.

Alves, H. \& Raposo, M. (2009). The measurement of the construct satisfaction in higher education. Service Industries Journal, 29, 203-218.

Anderson, J. C. \& Gerbing, D. W. (1988). Structural equation modeling in practice: A review and recommended two-step approach. Psychological Bulletin, 103, 411423.

Bagozzi, R. P. (1994). Structural Equation Models in marketing research: Basic principles. In R.P.Bagozzi (Ed.), Principles of Marketing Research, (pp. 317385). Malden, MA: Blackwell Publishers.

Bentler, P. M. (2002). EQS 6 Structural equations program manual. Encino, CA: Multivariate Software, Inc.

Boshoff, C. \& Mels, G. (1995). A causal model to evaluate the relationships among supervision, role stress, organizational commitment and internal service quality. European Journal of Marketing, 29, 23-42. 
Brough, P. (2005). A comparative investigation of the predictors of work-related psychological well-being within police, fire and ambulance workers. New Zealand Journal of Psychology, 34, 127-134.

Brown, S. P. \& Lam, S. K. (2008). A meta-nalysis of relationships linking employee satisfaction to customer responses. Journal of Retailing, 84, 243-255.

Brown, T. A. (2006). Confirmatory factor analysis for applied research. Guilford Press.

Byrne, B. (2006). Structural equation modelling with EQS: Basic concepts, applications and programming. London: Lawrence Erlbaum.

Cascio, W. (1989). Managing human resources: Productivity, QWL, profits. McGrawHill.

Chen, H. F. \& Chen, Y. C. (2008). The impact of work redesign and psychological empowerment on organizational commitment in a changing environment: An example from Taiwan's state-owned enterprises. Public Personnel Management, 37, 279-302.

Choi, Y. S., Seo, M. H., Scott, D., \& Martin, J. (2010). Validation of the organizational culture assessment instrument: An application of the Korean version. Journal of Sport Management, 24, 169-189.

Cicero, L., Pierro, A., \& van Knippenberg, D. (2010). Leadership and uncertainty: How role aAmbiguity affects the relationship between leader group prototypicality and leadership effectiveness. British Journal of Management, 21, 411-421.

Coelho, F. J., Augusto, M. G., Coelho, A. F., \& Sa, P. M. (2010). Climate perceptions and the customer orientation of frontline service employees. Service Industries Journal, 30, 1343-1357.

de Jong, R. D., van der Velde, M. E. G., \& Jansen, P. G. W. (2001). Openness to experience and growth need strength as moderators between job characteristics and satisfaction. International Journal of Selection and Assessment, 9, 350-356.

de Jonge, J., Dormann, C., Janssen, P. P. M., Dollard, M. F., Landeweerd, J. A., \& Nijhuis, F. J. N. (2001). Testing reciprocal relationships between job characteristics and psychological well-being: A cross-lagged structural equation model. Journal of Occupational and Organizational Psychology, 74, 29-46.

De Rijk, A., Nijhuis, F., \& Alexanderson, K. (2009). Gender differences in work modifications and changed job characteristics during the return-to-work process: A prospective cohort study. Journal of Occupational Rehabilitation, 19, 185193.

Ekinci, Y. \& Dawes, P. L. (2009). Consumer perceptions of frontline service employee personality traits, interaction quality, and consumer satisfaction. Service Industries Journal, 29, 503-521. 
Gonzalez, J. V. \& Garazo, T. G. (2006). Structural relationships between organizational service orientation, contact employee job satisfaction and citizenship behavior. International Journal of Service Industry Management, 17, 23-50.

Hackman, J. R. \& Oldham, G. R. (1980). Work redesign. Addison- Wesley.

Hair, J. F., Anderson, R. E., Tatham, R. L., \& Black, W. C. (1999). Análisis de datos multivariante. ( $4^{\circ}$ ed.) Prentice Hall.

Hogan, E. A. \& Martell, D. A. (1987). A confirmatory structural equations analysis of the job characteristics model. Organizational Behavior and Human dEcision Processes, 39, 242-263.

Houkes, I., Janssen, P. P. M., de Jonge, J., \& Bakker, A. B. (2003). Specific determinants of intrinsic work motivation, emotional exhaustion and turnover intention: A multisample longitudinal study. Journal of Occupational and Organizational Psychology, 76, 427-450.

Hsu, S.-H. \& Wang, Y.-C. (2008). The development and empirical validation of the Employee Satisfaction Index model. Total Quality Management, 19, 353-366.

Hung, H. \& Wong, Y. H. (2007). Organisational perception of customer satisfaction: Theories and evidence. Service Industries Journal, 27, 495-507.

Iglesias, V. (2009). The attribution of service failures: effects on consumer satisfaction. Service Industries Journal, 29, 127-141.

Janus, K., Amelung, V. E., Gaitanides, M., \& Schwartz, F. W. (2007). German physicians "on strike" - Shedding light on the roots of physician dissatisfaction. Health Policy, 82, 357-365.

Karasek, R., Kawakami, N., Brisson, C., Houtman, I., Bongers, P., \& Arnick, B. (1998). The Job Content Questionnaire (JCQ): An instrument for internationally comparative assessments of psychosocial job characteristics. Journal of Occupational Health Psychology, 3, 322-354.

Karatepe, O. M. \& Kilic, H. (2009). The effects of two directions of conflict and facilitation on frontline employees' job outcomes. Service Industries Journal, 29, 977-993.

Karsh, B., Booske, B. C., \& Sainfort, F. (2005). Job and organizational determinants of nursing home employee commitment, job satisfaction and intent to turnover. Ergonomics, 48, 1260-1281.

Kil, M., Leffelsend, S., \& Metz-Gockel, H. (2000). Diagnostic use of the Job Diagnostic Survey (JDS) in a revised and extended version for organizations and employees in the service and administration sector. Zeitschrift fur Arbeits-und Organisationspsychologie, 44, 115-128. 
Kristensen, T. S., Hannerz, H., Hogh, A., \& Borg, W. (2005). The Copenhagen Psychosocial Questionnaire-a tool for the assessment and improvement of the psychosocial work environment. Scand J Work Environ Health, 31, 438-449.

Kuo, C. M. (2007). The importance of hotel employee service attitude and the satisfaction of international tourists. Service Industries Journal, 27, 1073-1085.

Kuokkanen, L., Suominen, T., Harkonen, E., Kukkurainen, M. L., \& Doran, D. (2009). Effects of organizational change on work-related empowerment, employee satisfaction, and motivation. Nurs Adm Q, 33, 116-124.

Lee, S. M., Olson, D. L., Lee, S. H., Hwang, T., \& Shin, M. S. (2008). Entrepreneurial applications of the lean approach to service industries. Service Industries Journal, 28, 973-987.

Li, J. M., Yang, J. S., \& Wu, H. H. (2008). Improving service quality and organisation performance through human resource practices. A case study. Total Quality Management \& Business Excellence, 19, 969-985.

Lim, S., Ribeiro, D., \& Lee, S. M. (2008). Factors affecting the performance of entrepreneurial service firms. Service Industries Journal, 28, 1003-1013.

Lin, W. B. (2006). The exploration of employee involvement model. Expert Systems with Applications, 31, 69-82.

Linz, S. J. (2003). Job satisfaction among Russian workers. International Journal of Manpower, 24, 626-652.

Lopez-Cabarcos, M. A., Vazquez-Rodriguez, P., \& Montes-Pineiro, C. (2010). Bullying at work: Psychological antecedents and consequences on job satisfaction. Revista Latinoamericana de Psicologia, 42, 215-224.

Love, P. E. D., Irani, Z., Standing, C., \& Themistocleous, M. (2007). Influence of job demands, job control and social support on information systems professionals' psychological well-being. International Journal of Manpower, 28, 513-528.

Martín García, J., Luceño Moreno, L., Jaén Díaz, M., \& Rubio Valdehita, S. (2007). Relación entre factores psicosociales adversos, evaluados a través del cuestionario multidimensional Decore, y salud laboral deficiente. Psicothema, 19, 95-101.

Martínez Navarro, J. (2008). Primera enquesta de condicions de treball de Catalunya. Barcelona: Generalitat de Catalunya. Departament de Treball. Direcció General de Relacions Laborals.

Mohr, G. \& Wolfram, H. J. (2010). Stress among managers: The importance of dynamic tasks, predictability, and social support in unpredictable times. Journal of Occupational Health Psychology, 15, 167-179.

Moncada Lluis, S., Llorens Serrano, C., Font Corominas, A., Galtes Camps, A., \& Navarro Gine, A. (2008). Psychosocial risk exposure among wage earning 
population in Spain (2004-05): reference values of the 21 dimensions of COPSOQ ISTAS21 questionnaire. Rev Esp Salud Publica, 82, 667-675.

Moncada, S., Llorens, C., \& Kristensen, T. S. (2004). Método istas-21(CoPsoQ). Manual para la evaluación de riesgos psicosociales en el trabajo. Barcelona: Instituto Sindical del Trabajo Ambiente y Salud.

Moncada, S., Llorens, C., Navarro, A., \& Kristensen, T. S. (2005). IST AS21: Versión en lengua castellana del cuestionario psicosocial de Copenhague (COPSOQ). Arch Prev Riesgos Labor, 8, 18-29.

Moncada, S., Petersen, JH, Navarro, A., Llorens, C., Burr, H, Hasle, Peter, and Bjorner, J. B (2010). Psychosocial work environment and its association with socioeconomic status. A comparison of Spain and Denmark. Scandinavian Journal of Public Health

Morrison, D., Cordery, J., Girardi, A., \& Payne, R. (2005). Job design, opportunities for skill utilization, and intrinsic job satisfaction. European Journal of Work and Organizational Psychology, 14, 59-79.

Nielsen, K. \& Cleal, B. (2010). Predicting flow at work: Investigating the activities and job characteristics that predict flow states at work. Journal of Occupational Health Psychology, 15, 180-190.

Noblet, A., Graffam, J., \& McWilliams, J. (2008). Sources of well-being and commitment of staff in the Australian Disability Employment Services. Health \& Social Care in the Community, 16, 137-146.

Noblet, A., Teo, S. T. T., McWilliams, J., \& Rodwell, J. J. (2005). Which work characteristics predict employee outcomes for the public-sector employee? An examination of generic and occupation-specific characteristics. International Journal of Human Resource Management, 16, 1415-1430.

Nübling, M., Stössel, U., Hasselhorn, H.-M., Michaelis, M., \& Hofmann, F. (2006). Measuring psychological stress and strain at work: Evaluation of the COPSOQ Questionnaire in Germany. GMS Psycho-Social-Medicine, 3, 1-14.

Paulin, M., Ferguson, R. J., \& Bergeron, J. (2006). Service climate and organizational commitment: The importance of customer linkages. Journal of Business Research, 59, 906-915.

Petrescu, A. I. \& Simmons, R. (2008). Human resource management practices and workers' job satisfaction. International Journal of Manpower, 29, 651-667.

Pires, C. P., Sarkar, S., \& Carvalho, L. (2008). Innovation in services - how different from manufacturing? Service Industries Journal, 28, 1339-1356.

Ritter, J. A. \& Anker, R. (2002). Good jobs, bad jobs: Workers' evaluations in five countries. International Labour Review, 141, 331-+. 
Roelen, C. A. M., Koopmans, P. C., \& Groothoff, J. W. (2008). Which work factors determine job satisfaction? Work, 30, 433-439.

Rooney, J. A., Gottlieb, B. H., \& Newby-Clark, I. R. (2009). How support-related managerial behaviors influence employees An integrated model. Journal of Managerial Psychology, 24, 410-427.

Sakires, J., Doherty, A., \& Misener, K. (2009). Role ambiguity in voluntary sport organizations. Journal of Sport Management, 23, 615-643.

Sanchis-Palacios, J. R. \& Ribeiro, D. (2010). Contingency factors on the success of services for social integration and job placement schemes. Service Industries Journal, 30, 339-357.

Schyns, B. \& Croon, M. A. (2006). A model of task demands, social structure, and leader-member exchange and their relationship to job satisfaction. International Journal of Human Resource Management, 17, 602-615.

Scott, A., Gravelle, H., Simoens, S., Bojke, C., \& Sibbald, B. (2006). Job satisfaction and quitting intentions: A structural model of British general practitioners. British Journal of Industrial Relations, 44, 519-540.

Sellgren, S. F., Ekvall, G., \& Tomson, G. (2008). Leadership behaviour of nurse managers in relation to job satisfaction and work climate. Journal of Nursing Management, 16, 578-587.

Shiu, Y. M. \& Yu, T. W. (2010). Internal marketing, organisational culture, job satisfaction, and organisational performance in non-life insurance. Service Industries Journal, 30, 793-809.

Skakon, J., Nielsen, K., Borg, V., \& Guzman, J. (2010). Are leaders' well-being, behaviours and style associated with the affective well-being of their employees? A systematic review of three decades of research. Work and Stress, 24, 107-139.

Snipes, R. L., Oswald, S. L., LaTour, M., \& Armenakis, A. A. (2005). The effects of specific job satisfaction facets on customer perceptions of service quality: an employee-level analysis. Journal of Business Research, 58, 1330-1339.

Sparr, J. L. \& Sonnentag, S. (2008). Fairness perceptions of supervisor feedback, LMX, and employee well-being at work. European Journal of Work and Organizational Psychology, 17, 198-225.

Spreitzer, G. M. (1995). Psychological empowerment in the workplace - dimensions, measurement, and validation. Academy of Management Journal, 38, 1442-1465.

Srivastava, R. \& Rangarajan, D. (2008). Understanding the salespeople's "feedbacksatisfaction" linkage: what role does job perceptions play? Journal of Business \& Industrial Marketing, 23, 151-159. 
Stetz, M. C., Castro, C. A., \& Bliese, P. D. (2007). The impact of deactivation uncertainty, workload, and organizational constraints on reservists' psychological well-being and turnover intentions. Military Medicine, 172, 576580.

Stocker, D., Jacobshagen, N., Semmer, N. K., \& Annen, H. (2010). Appreciation at work in the Swiss armed forces. Swiss Journal of Psychology, 69, 117-124.

Tari, J. J., Molina, J. F., \& Castejón, J. L. (2007). The relationship between quality management practices and their effects on quality outcomes. European Journal of Operational Research, 183, 483-501.

Taris, T. W., Schreurs, P. J. G., Eikmans, K. J. L., \& van Riet, P. (2008). Work characteristics, well-being and organizational performance: an organizationallevel test of the happy-productive worker hypothesis. Gedrag \& Organisatie, 21, 3-18.

ter Doest, L. \& de Jonge, J. (2006). Testing causal models of job characteristics and employee well-being: A replication study using cross-lagged structural equation modelling. Journal of Occupational and Organizational Psychology, 79, 499507.

Thompson, C. A. \& Prottas, D. J. (2006). Relationships among organizational family support, job autonomy, perceived control, and employee well-being. Journal of Occupational Health Psychology, 11, 100-118.

Tian, X. Z. \& Pu, Y. J. (2008). An artificial neural network approach to hotel employee satisfaction: The case of China. Social Behavior and Personality, 36, 467-482.

Tortosa-Edo, V., Sanchez-Garcia, J., \& Moliner-Tena, M. A. (2010). Internal market orientation and its influence on the satisfaction of contact personnel. Service Industries Journal, 30, 1279-1297.

Tummers, G. E. R., Landeweerd, J. A., \& Van Merode, G. G. (2002). Work organization, work characteristics, and their psychological effects on nurses in the Netherlands. International Journal of Stress Management, 9, 183-206.

Tummers, G. E. R., Van Merode, G. G., \& Landeweerd, J. A. (2006). Organizational characteristics as predictors of nurses' psychological work reactions. Organization Studies, 27, 559-584.

Ullman, J. B. \& Bentler, P. M. (2004). Structural Equation Modeling. In M.Hardy \& A. Bryman (Eds.), Handbook of Data Analysis (pp. 431-458). SAGE.

Uppal, S. (2005). Disability, workplace characteristics and job satisfaction. International Journal of Manpower, 26, 336-349.

Van den Broeck, A., Vansteenkiste, M., De Witte, H., \& Lens, W. (2008). Explaining the relationships between job characteristics, burnout, and engagement: The role of basic psychological need satisfaction. Work and Stress, 22, 277-294. 
Wakkee, I., Elfing, T., \& Monaghan, S. (2010). Creating entrepreneurial employees in traditional service sectors. The role of coaching and self-efficacy. International Entrepeneurship Management, 6, 1-21.

Yang, J. T. (2009). Individual attitudes to learning and sharing individual and organisational knowledge in the hospitality industry. Service Industries Journal, 29, 1723-1743.

Yu, S. F., Gu, G. Z., Zhou, W. H., \& Wang, S. (2008). Psychosocial work environment and well-being: A cross-sectional study at a thermal power plant in China. Journal of Occupational Health, 50, 155-162.

Zacharatos, A., Hershcovis, M. S., Turner, N., \& Barling, J. (2007). Human resource management in the North American automotive industry - A meta-analytic review. Personnel Review, 36, 231-254.

Zarafshani, K. \& Alibaygi, A. H. (2009). Predictors of job satisfaction among academics at an Iranian university. Psychological Reports, 104, 633-644. 


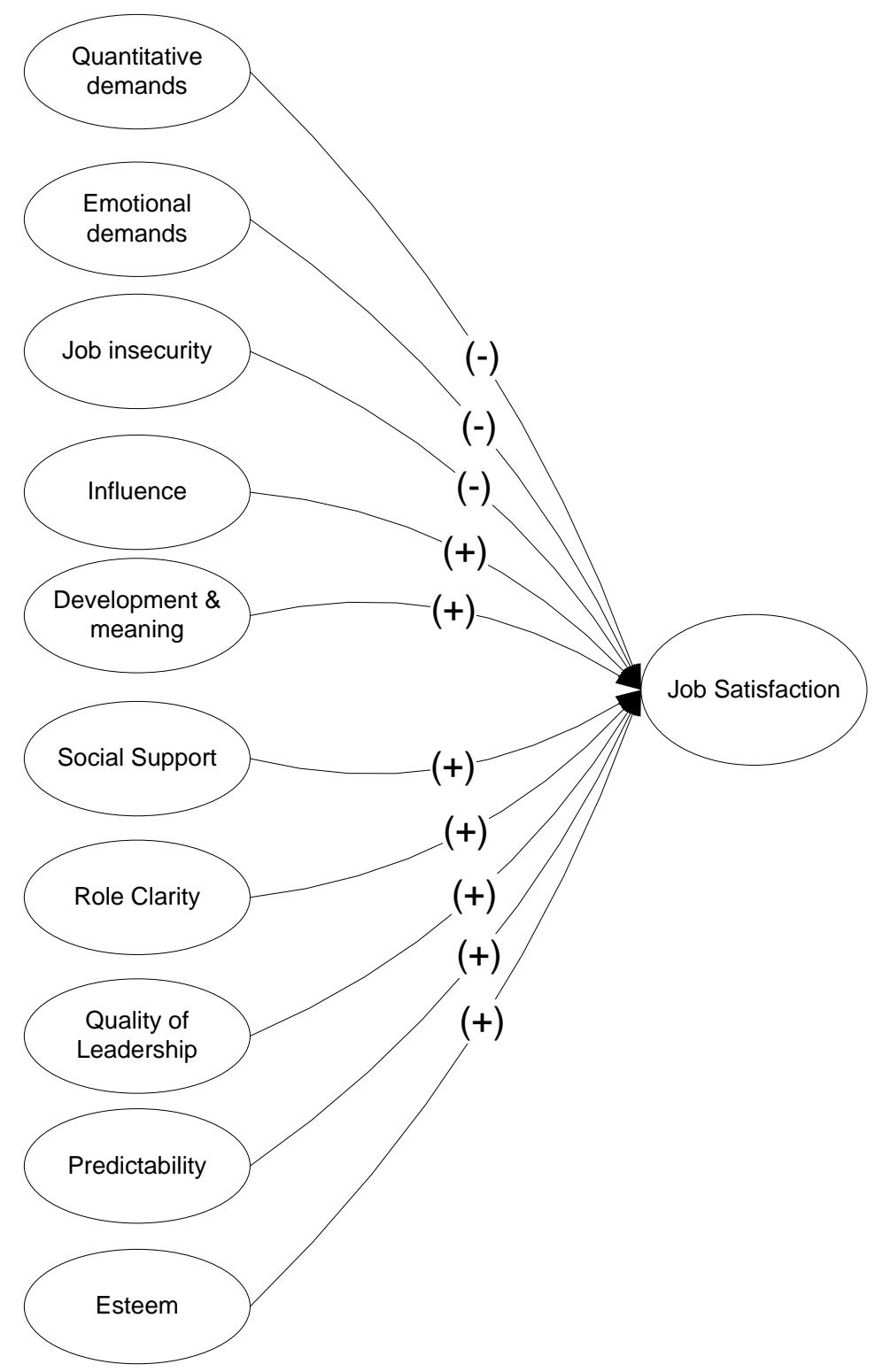

Figure 1.- Integrating model of the effect of working conditions on job satisfaction. 


\begin{tabular}{|c|c|c|c|}
\hline & $\mathrm{n}$ & $\%$ & Sample error $(\%)$ \\
\hline \multicolumn{4}{|l|}{ Gender } \\
\hline Male & 620 & 39.9 & 2.4 \\
\hline Female & 933 & 60.1 & 2.7 \\
\hline \multicolumn{4}{|l|}{ Age } \\
\hline $16-24$ & 213 & 13.7 & \\
\hline $25-34$ & 507 & 32.6 & \\
\hline $35-44$ & 329 & 21.2 & \\
\hline $45-54$ & 322 & 20.7 & \\
\hline $55-64$ & 173 & 11.1 & \\
\hline$>64$ & 9 & 0.6 & \\
\hline \multicolumn{4}{|l|}{ Company size } \\
\hline$<6$ & 190 & 12.2 & 5.6 \\
\hline $6-49$ & 542 & 34.9 & 2.8 \\
\hline $50-249$ & 323 & 20.8 & 3.7 \\
\hline$>249$ & 498 & 32.1 & 3.5 \\
\hline \multicolumn{4}{|l|}{ Activity sector } \\
\hline Public administration/Banking 1 & 339 & 21.8 & 5.4 \\
\hline Commerce/Catering trade $^{2}$ & 455 & 29.3 & 4.7 \\
\hline Social services ${ }^{3}$ & 347 & 22.3 & 5.4 \\
\hline Other services ${ }^{4}$ & 412 & 26.5 & 4.9 \\
\hline
\end{tabular}

${ }^{1}$ Public administration, defence department, social security, banking and finance, insurance companies.

${ }^{2}$ Wholesale and retail trade, catering/hotel management trade.

${ }^{3}$ Research, education, health and social services and associated activities.

${ }^{4}$ Travel, transport, post office, telecommunications, environmental and industrial cleaning, sport and leisure.

Table 1. Demographic characteristics of study sample. 


\begin{tabular}{|c|c|c|c|}
\hline Factor & Item & Description & $\begin{array}{l}\text { Cronbach's } \\
\text { alpha }\end{array}$ \\
\hline \multirow[t]{3}{*}{ Quantitative demands } & $34 . \mathrm{a}$ & Do you have to work very fast? & 0.51 \\
\hline & $34 . b$ & Is your workload unevenly distributed so it piles up? & \\
\hline & 34.cIn & vHow often do you not have time to complete all your work tasks? & \\
\hline \multirow[t]{3}{*}{ Emotional demands } & 34.d & Does your work require that you hide your feelings? & 0.71 \\
\hline & 34.e & Is it hard for you to forget the problems of your work? & \\
\hline & 34.f & Is your work emotionally demanding? & \\
\hline \multirow[t]{4}{*}{ Job insecurity } & $40 . \mathrm{a}$ & $\begin{array}{l}\text { Are you worried about it being difficult for you to find another job if you } \\
\text { became unemployed? }\end{array}$ & 0.78 \\
\hline & 40.b & Are you worried about being transferred to another job against your will? & \\
\hline & 40.c & $\begin{array}{l}\text { Are you worried about your working hours being changed against your } \\
\text { will? }\end{array}$ & \\
\hline & 40.d & Are you worried about your salary being changed? & \\
\hline \multirow[t]{5}{*}{ Influence at work } & $35 . \mathrm{a}$ & Can you influence the amount of work assigned to you? & 0.71 \\
\hline & $35 . b$ & $\begin{array}{l}\text { Is it your opinion taken into account when the boss assigns you your } \\
\text { work? }\end{array}$ & \\
\hline & 35.c & Can you influence the order in which you perform your tasks? & \\
\hline & $35 . d$ & Can you decide when to take a break? & \\
\hline & $35 . \mathrm{e}$ & $\begin{array}{l}\text { If you have a personal or family matter to attend to, can you leave your } \\
\text { place of work for at least an hour without having to ask special } \\
\text { permission? }\end{array}$ & \\
\hline \multirow{5}{*}{$\begin{array}{l}\text { Development \& } \\
\text { Meaning }\end{array}$} & $36 . \mathrm{a}$ & Does your work require you to take the initiative? & 0.77 \\
\hline & $36 . b$ & Do you have the possibility of learning new things through your work? & \\
\hline & 36.c & Do you feel committed to your work? & \\
\hline & $36 . d$ & Is your work meaningful? & \\
\hline & 36.e & Do you enjoy telling others about your place of work? & \\
\hline \multirow[t]{4}{*}{ Social support } & $38 . \mathrm{a}$ & How often do you get help and support from your colleagues? & 0.76 \\
\hline & $38 . b$ & How often do you get help and support from your immediate superior? & \\
\hline & 38.cIn & vIs your workplace not isolated from your peers? & \\
\hline & 38.d & Do you feel part of a community at your place of work? & \\
\hline \multirow[t]{2}{*}{ Role clarity } & $37 . \mathrm{a}$ & Do you know exactly what degree of autonomy you have in your work? & 0.55 \\
\hline & 37.b & Do you know exactly which areas are your responsibilities? & \\
\hline \multirow[t]{2}{*}{ Quality of leadership } & 38.e & $\begin{array}{l}\text { To what extent would you say that your immediate superior is good at } \\
\text { work planning? }\end{array}$ & 0.77 \\
\hline & $38 . f$ & $\begin{array}{l}\text { To what extent would you say that your immediate superior communicate } \\
\text { well with workers? }\end{array}$ & \\
\hline \multirow[t]{2}{*}{ Predictability } & 37.c & $\begin{array}{l}\text { At your place of work, are you informed well in advance concerning } \\
\text { changes for the future? }\end{array}$ & 0.74 \\
\hline & 37.d & $\begin{array}{l}\text { Do you receive all the information you need in order to do your work } \\
\text { well? }\end{array}$ & \\
\hline \multirow[t]{3}{*}{ Esteem } & $39 . \mathrm{a}$ & Do your superiors give you the recognition you deserve? & 0.88 \\
\hline & $39 . b$ & $\begin{array}{l}\text { In difficult situations, do you get the necessary support from your } \\
\text { superiors? }\end{array}$ & \\
\hline & 39.c & $\begin{array}{l}\text { If you think about all the work and effort you have made, do you think } \\
\text { you receive proper recognition for your work? }\end{array}$ & \\
\hline
\end{tabular}

Table 2. Working condition factors (Nübling, Stössel, Hasselhorn, Michaelis, \&

Hofmann, 2006; Moncada et al., 2005; Moncada et al., 2004). Items numbers ending

with 'Inv' were reverse coded. 


\begin{tabular}{|c|c|c|c|c|c|c|c|c|c|c|}
\hline & (1) & (2) & (3) & (4) & (5) & (6) & (7) & (8) & (9) & (10) \\
\hline (1) Quantitative demands & - & & & & & & & & & \\
\hline (2) Emotional demands & $0.42 * *$ & - & & & & & & & & \\
\hline (3) Job insecurity & 0.00 & $0.18 * *$ & - & & & & & & & \\
\hline (4) Influence at work & $-0.22 * *$ & 0.02 & 0.00 & - & & & & & & \\
\hline $\begin{array}{l}\text { (5) Development \& } \\
\text { Meaning }\end{array}$ & $-0.22 * *$ & $0.15^{* *}$ & -0.04 & $0.58 * *$ & - & & & & & \\
\hline (6) Social support & $-0.21 * *$ & $-0.16^{* *}$ & $-0.26 * *$ & $0.30 * *$ & $0.40 * *$ & - & & & & \\
\hline (7) Role clarity & $-0.18 * *$ & $-0.18 * *$ & $-0.20 * *$ & $0.39 * *$ & $0.47 * *$ & $0.38 * *$ & - & & & \\
\hline (8) Quality of leadership & $-0.41 * *$ & $-0.32 * *$ & -0.05 & $0.35 * *$ & $0.46^{* *}$ & $0.58 * *$ & $0.41 * *$ & - & & \\
\hline (9) Predictability & $-0.44 * *$ & $-0.34 * *$ & $-0.23 * *$ & $0.33^{* *}$ & $0.35^{* *}$ & $0.51^{* *}$ & $0.61 * *$ & $0.72 * *$ & - & \\
\hline (10) Esteem & $-0.36^{* *}$ & $-0.33 * *$ & $-0.16^{* *}$ & $0.45 * *$ & $0.45^{* *}$ & $0.46^{* *}$ & $0.37 * *$ & $0.74 * *$ & $0.58 * *$ & - \\
\hline (11) Job satisfaction & $-0.38^{* *}$ & $-0.33^{* *}$ & $-0.21 * *$ & $0.33^{* *}$ & $0.39^{* *}$ & $0.46^{* *}$ & $0.31^{* *}$ & $0.57^{* *}$ & $0.53^{* *}$ & $0.65^{* *}$ \\
\hline
\end{tabular}

Table 3. Correlation between constructs. Significance: $* * 1 \%$ 


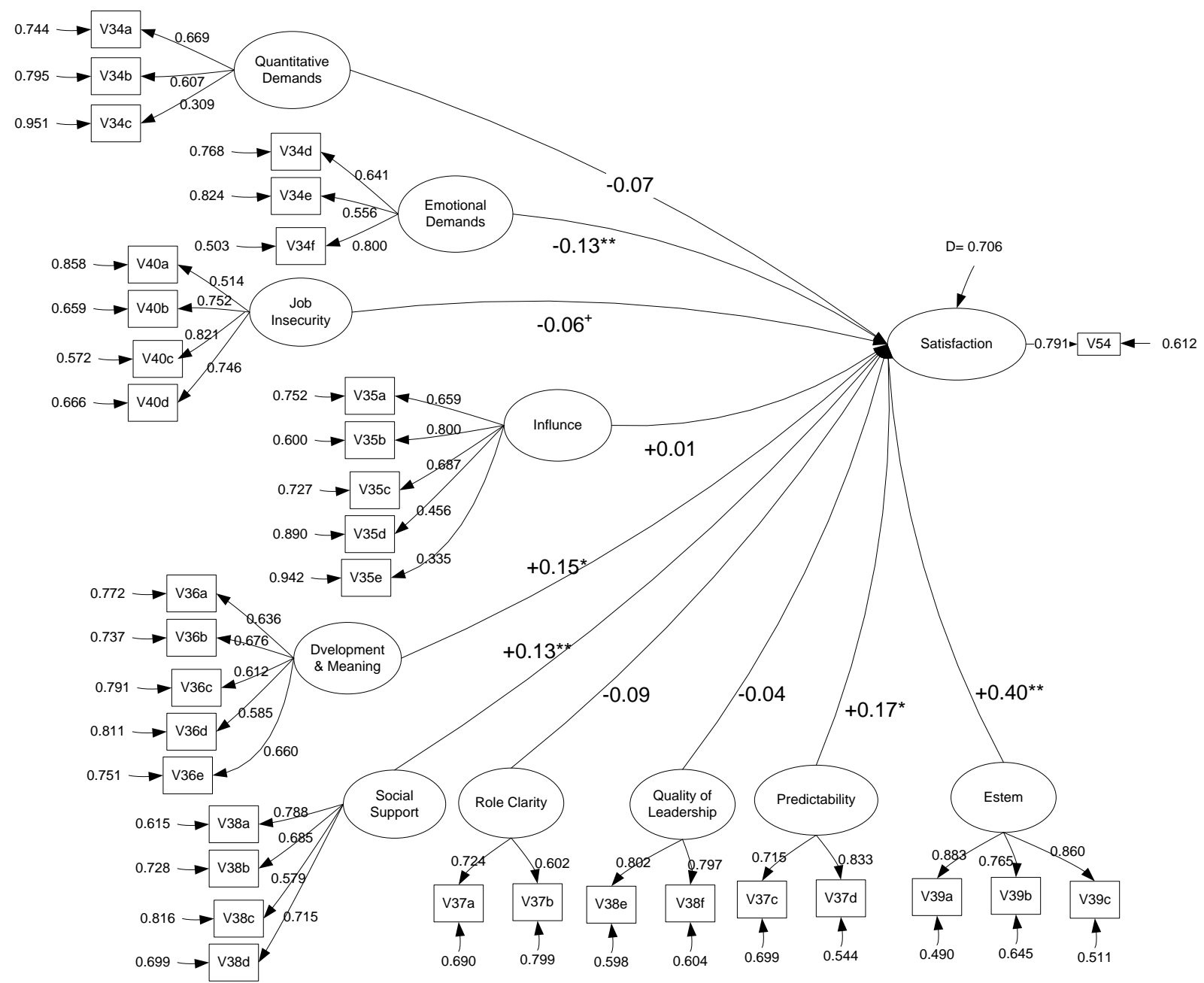

Figure 2. Full latent structural model of the relationships between working conditions on job satisfaction. The correlations between the explanatory variables are included in the model but are not showed in the figure for clarity. Coefficients represent standardized estimates. Significance for effects in structural model: $+10 \% ; * 5 \%$; ** $1 \%$ 